\title{
STUDI KOMUNITAS NYAMUK PENYEBAB FILARIASIS DI DESA BOJONG KABUPATEN LAMPUNG TIMUR
}

\author{
Suharno Zen \\ Pendidikan Biologi FKIP Universitas Muhammadiyah Metro \\ E-mail: suharnozein@gmail.com
}

\begin{abstract}
Filariasis is a disease caused by species offilarial worms Wuchereria bancrofti, Brugia malayi and Brugia timori and spread by the Anopheles mosquito, and Culex sp Mansonia sp. It is known that nematodes cause filariasis in District Sekampung Udik East Lampung district are a species Brugia sp. This study was conducted in one of the houses in the village of Bojong filariasis patients in March-May 2013. The arrest of mosquitoes made 1 times a week for 1 month from the hours 18:00-06:00. The method used for catching mosquitoes is to use bait human foot (human landing) for 20 minutes, and break every 5 minutes. The arrest was made by investigators assisted by two local residents by using the tool aspirometer. Mosquitoes were then taken to the Laboratory of Parasitology Entomology section of the Faculty of Medicine, the University of Gadjah Mada in Yogyakarta for mosquitoes identified using identification keys. Besides observations to the environmental conditions around the homes of people. From the results obtained in 1020 catching mosquitoes which consists of seven species of mosquito that is; Culex tritaeniorhynchus (420), Cx. fasciatus (48), Mansonia uniformis (152), Ma. dives (56), Ma. annulifera (4), Ma. annulata (4) and mosquito Anopheles (336). State of the environment in the village of Bojong subdistrict Sekampung Udik the form fields as rubber, cocoa, swamps, paddy fields potentially provide breeding grounds for mosquitoes filariasis. Further research is needed to determine the value of microfilaria rate and mosquito vector bionomics offilariasis.
\end{abstract}

Kata kunci : filariasis, identifikasi, human landing, mikrofilaria rate

Filariasis adalah suatu penyakit yang disebabkan oleh cacing filaria spesies Wuchereria bancrofti, Brugia timori dan Brugia malayi. Filariasis masih menjadi masalah kesehatan di Indonesia dan tersebar dari Sumatera hingga Papua (DepKes. RI., 2005). Filariasis yang disebabkan oleh cacing B. malayi ditemukan paling banyak dan mempunyai daerah penyebaran paling luas di Indonesia terutama di luar Pulau Jawa, misalnya di Sumatera, Kalimantan dan Sulawesi. Umumnya daerah endemis filariasis di daerah pedesaan (rural) adalah di persawahan, rawarawa, pantai, dan hutan, sedangkan untuk daerah perkotaan (urban) biasanya dijumpai di got-got, comberan, dan saluran air. Tempat tersebut merupakan breeding place bagi kehidupan vektor, sehingga ada keterkaitan antara lingkungan yang mendukung untuk menjadi tempat breeding, manusia sebagai host dan nyamuk sebagai vektornya (DepKes. RI., 2006). B. malayi tipe periodisitas nokturnal vektor nyamuknya adalah Anopheles barbirostris, dan zoonosis tipe sub periodik nokturnal dengan vektor nyamuk Mansonia indiana, Ma. annulifera, Ma.annulata, dan Ma.dives (Soeyoko, 1998). 
Data Departemen Kesehatan RI tahun 2006 diperkirakan 11.473 orang terinfeksi Filariasis, pada tahun 2010 diperkirakan 11.968 orang terinfeksi Filariasis, pada tahun 2011 diperkirakan 10.250 orang terinfeksi Filariasis, pada tahun 2012-2013 diperkirakan 8.914 orang terinfeksi Filariasis. Berdasarkan data Dinas Kesehatan Kabupaten Lampung Timur pada tahun 2004 - 2007 dari 500 hasil sampel darah yang diperiksa terdapat 139 kasus filariasis dan untuk kasus kronisnya tercatat 36 orang, sedangkan yang meninggal sudah 2 orang. Dari 11 kecamatan yang ada di Kabupaten Lampung Timur, Desa Bojong yang ada di Kecamatan Sekampung Udik terdapat kasus kronis terbanyak yaitu 8 orang, sedangkan mikrofilaria ratenya sebesar 4,17\% (DinKes. Kab. Lampung Timur, 2006). Kabupaten Lampung Timur dengan jumlah penduduk tahun 2004 sekitar 914.603 jiwa bekerja di sektor pertanian pangan, perdagangan, industri dan lain-lain. Penggunaan lahan di Kabupaten Lampung Timur terdiri dari lahan sawah, perkebunan, hutan produksi dan hutan suaka marga satwa seluas 22.292,5 ha atau 23,59 \% (DinKes. Kab. Lampung Timur, 2006).

Hasil data sekunder diketahui bahwa nematoda penyebab filariasis di Kecamatan Sekampung Udik Kabupaten Lampung Timur adalah spesies Brugia malayi (DinKes. Kab. Lampung Timur, 2005), sedangkan survei entomologi untuk menentukan spesies nyamuk vektornya belum pernah dilakukan. Berdasarkan latar belakang tersebut di atas maka penelitian ini bertujuan untuk mengetahui komunitas nyamuk apa saja di Desa Bojong
Kecamatan Sekampung Udik Kabupaten Lampung Timur. Hal ini diharapkan dengan mengetahui spesies nyamuk dapat dilakukan kegiatan untuk memutuskan mata rantai penularan dan mencegah transmisi filariasis dari suatu daerah ke daerah lain.

\section{METODE}

Penelitian ini dilaksanakan di salah satu rumah penderita filariasis di Desa Bojong pada bulan Maret Mei 2013. Penangkapan nyamuk dilakukan 1 kali dalam seminggu selama 1 bulan dari jam 18:00-06:00 sesuai dengan aktivitas nyamuk vektor filariasis dalam menghisap darah. Metode yang digunakan untuk penangkapan nyamuk adalah dengan menggunakan umpan kaki manusia (human landing) selama 20 menit, dan istirahat setiap 5 menit. Penangkapan dilakukan oleh peneliti dibantu 2 warga setempat dengan menggunakan alat aspirometer. Nyamuk kemudian dipindahkan ke paper cup yang diberi label (jumlah yang tertangkap, tanggal, lokasi). Nyamuk yang diperoleh selanjutnya dibawa ke Laboratorium Parasitologi bagian Entomologi Fakultas Kedokteran Universitas Gadjah Mada Yogyakarta untuk diidentifikasi menggunakan kunci identifikasi larva dan nyamuk dari Departemen Kesehatan RI. Selain itu dilakukan pengamatan secara langsung (observasi) terhadap kondisi lingkungan sekitar rumah penderita dan lingkungan di tempat penderita melakukan aktifitas seharihari untuk melihat hubungan antara lingkungan tempat berkembangbiak dengan keberadaan komunitas nyamuk vektor filariasis. 


\section{HASIL}

Tabel 1. Hasil penangkapan nyamuk Desa Bojong Kecamatan Sekampung Udik Kabupaten Lampung Timur pada bulan Maret - Mei 2013

\begin{tabular}{l} 
No. Spesies \\
1. Culex tritaeniorhynchus \\
2. Cx. fasciatus \\
3. Mansonia uniformis \\
4. Ma. dives \\
5. Ma. annulifera \\
6. Ma. annulata \\
7. Anopheles spp \\
\hline Total \\
\hline Foto 1. Nyamuk Culex spp
\end{tabular}

\section{PEMBAHASAN}

Dari hasil penangkapan nyamuk yang dilaksanakan dari pukul 18.00 WIB - 06.00 WIB mendapatkan nyamuk sebanyak 1020 ekor yang terdiri dari 7 spesies nyamuk yaitu; Culex tritaeniorhynchus (420 ekor), $C x$. fasciatus (48 ekor), Mansonia uniformis (152 ekor), Ma. dives (56 ekor), Ma. annulifera (4 ekor), Ma. annulata (4 ekor) dan nyamuk Anopheles sp (336 ekor). Dari ke 7 spesies nyamuk tersebut, proporsi nyamuk tertangkap yang paling
Jumlah (ekor)

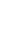

Jumlah (ekor)
80
52
6
36
36 
bahwa faktor lingkungan terdapat hubungan yang signifikan terhadap kejadian filariasis. Keadaan lingkungan di sekitar rumah (semaksemak/pohon) dan di dalam rumah juga mendukung untuk terkena risiko filariasis. Febrianto dkk, (2008) menjelaskan bahwa keberadaan kandang ternak di dekat rumah mempunyai dampak yang besar untuk tertular filariasis. Kandang ternak mempunyai temperatur dan kelembaban ideal untuk nyamuk vektor filariasis berkembangbiak, maka secara langsung juga akan meningkatkan risiko untuk tertular filariasis dibandingkan mereka yang tidak memiliki kandang ternak di luar rumah. Hasil penangkapan nyamuk ternyata diperoleh nyamuk $C x$. tritaeniorhynchus paling dominan diantara nyamuk lain sebanyak 420 ekor. Hal ini dapat dijelaskan bahwa di sekitar lingkungan pemukiman penduduk terdapat parit dan genangan air yang kotor berasal dari saluran pembuangan limbah rumah tangga dan keperluan MCK (mandi, cuci, kakus) di belakang rumah yang tercemar sehingga merupakan tempat yang sesuai untuk tempat berkembang biak nyamuk tersebut. Begitu pula dengan semak-semak, pohon karet dan pohon cokelat yang banyak terdapat di sekitar rumah. Keberadaan parit, semak-semak, tempat penampungan getah karet yang terbuat dari batok kelapa menjadi tempat berkembangbiak nyamuk Culex sp. (Sembel, 2009).

Hasil penangkapan nyamuk juga diperoleh nyamuk Mansonia spp sebanyak 216 ekor. Hal ini dikarenakan karena pemukiman penduduk berdekatan dengan daerah rawa-rawa yang dipenuhi oleh tanaman enceng gondok (Eichornia crassipes) yang menutupi permukaan air sehingga juga sangat dimungkinkan daerah rawa-rawa tersebut menjadi breeding place bagi nyamuk Mansonia spp. Jumlah nyamuk Anopheles sp yang tertangkap sebanyak 336 ekor, kemungkinan terbanyak adalah spesies Anopheles barbirostris. Hal ini dimungkinkan karena daerah persawahan menjadi tempat berkembangbiak bagi nyamuk tersebut.

Keadaan lingkungan di desa Bojong Kecamatan Sekampung Udik yang berupa ladang, rawa, dan sawah didominasi oleh tumbuhan karet, cokelat dan padi. Lingkungan tersebut berpotensi menyediakan tempat berkembangbiak bagi vektor. Hal ini dijelaskan oleh (Soedomo, 1990), bahwa keadaan ekologi daerah sangat penting karena dengan melihat keadaan ekologinya dapat diperkirakan filariasis apa yang endemik di daerah tersebut. Bila daerah tersebut berupa dataran rendah, banyak rawa-rawa dan kebun karet kemungkinan $B$. malayi di daerah tersebut cukup besar

Pada pengukuran temperatur ruangan di lokasi penangkapan berkisar antara $27^{\circ} \mathrm{C}-28^{\circ} \mathrm{C}$. Gandahusada, dkk (2003) menyatakan bahwa nyamuk dapat hidup dengan baik pada suhu $24^{\circ} \mathrm{C}-39^{\circ} \mathrm{C}$.

\section{KESIMPULAN DAN SARAN Kesimpulan}

Berdasarkan hasil penelitian dapat disimpulkan bahwa:

1. Terdapat 7 spesies nyamuk yang ditangkap di desa Bojong Kecamatan Sekampung Udik yaitu ; nyamuk Culex tritaeniorhyncus sebanyak 420 ekor, selanjutnya berturut-turut Anopheles sp 336 ekor, 
Mansonia uniformis 152 ekor, $M a$. dives 56 ekor, $C x$. fasciatus 48 ekor, Ma. annulifera dan nyamuk Ma. annulata masingmasing 4 ekor.

2. Keadaan lingkungan di desa Bojong Kecamatan Sekampung Udik yang berupa ladang karet, cokelat, rawa, dan sawah berpotensi menyediakan tempat berkembangbiak bagi nyamuk vek tor filariasis.

\section{Saran}

Adanya penelitian lanjutan tentang nilai mikrofilaria rate ( $m f$ rate) setelah adanya program Elkaga dan studi bionomik untuk melihat perilaku serta masih ada/tidaknya larva infektif pada nyamuk vektor filariasis di desa Bojong Kecamatan Sekampung Udik

\section{DAFTAR RUJUKAN}

Achmadi, U. F. 2005. Manajemen Penyakit Berbasis Wilayah. Penerbit Buku Kompas. Jakarta.

Dep. Kes. RI., 2005. Pedoman Program Eliminasi Filariasis di Indonesia. DitJen PPM\&PL. Jakarta.

Dep. Kes. RI., 2006. Epidemiologi Filariasis. DitJen PPM\&PL. Jakarta.

Din. Kes. Kab. Lampung Timur, 2005. Laporan Eliminasi Filariasis Kabupaten Lampung Timur. Lampung

Din. Kes. Kab. Lampung Timur, 2006. Profil Kesehatan Kabupaten Lampung Timur. Lampung.
Febrianto, B, Astri, M, Widiarti, I. 2008. Faktor Risiko Filariasis di Desa Samborejo Kecamatan Tirto Kabupaten Pekalongan Jawa Tengah. Buletin Penelitian Kesehatan. $36(2): 48-58$.

Saniambara, N. 2005. Filariasis dan Beberapa Faktor Yang Berhubungan Dengan Penularannya di Kecamatan Rote Timur Kabupaten Rote Ndao Provinsi Nusa Tenggara Timur. Tesis. Program Pascasarjana UGM. Yogyakarta.

Sembel, D. T. 2009. Entomologi Kedokteran. Yogyakarta: CV. ANDI OFFSET

Soedomo, M. 1990. Aspek Epidemiologi Filariasis yang Berhubungan Dengan Pemberantasannya. Cermin Dunia Kedokteran. No. 64: 11-13.

Soeyoko.1998. Pengembangan Antibodi Monoklonal Spesifik Terhadap Antigen Beredar Brugia malay. 